\title{
TRENCH FEVER.
}

\section{FINAL REPORT OF THE WAR OFFICE TRENCH FEVER INVESTIGATION COMMITTEE.}

\author{
EDITED BY \\ MAJOR GENERAL SIR DAVID BRUCE, A.M.S. \\ CHAIRMAN.
}

CONTENTS.

INTRODUCTION

I. IN WHAT TISSUES OF THE BLOOD IS THE ORGANISM OF TRENCH FEVER FOUND? . 259

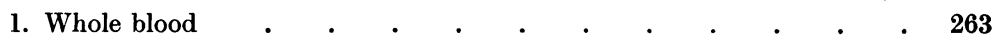

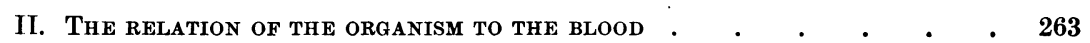

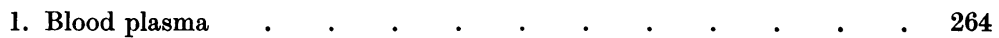

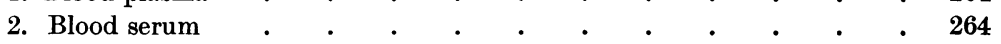

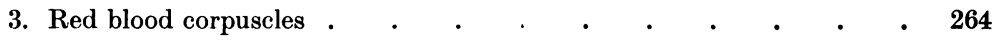

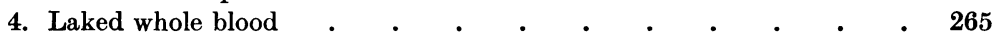

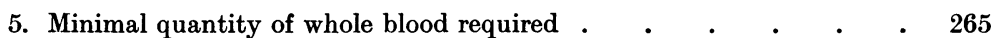

6. Inoculation of scarified area of skin by whole blood . $\quad . \quad$ - $\quad 266$

7. When does the blood become infective? . . . . . . $\quad$ - 266

8. How long does the blood remain infective? . . . . . $\quad$ - 267

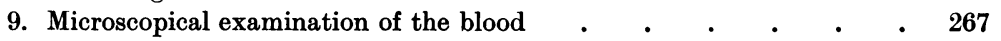

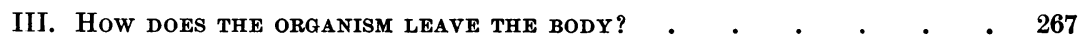

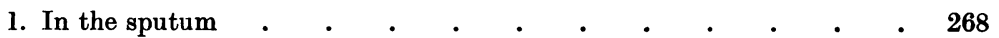

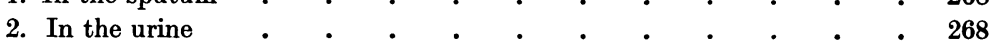

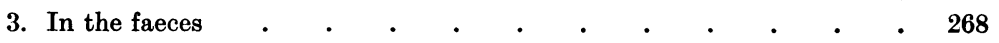

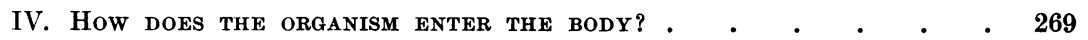

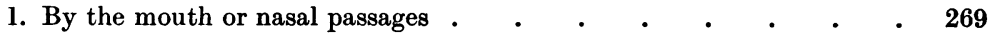

2. Through the conjunctiva and other mucous membranes $\quad$ • $\quad$ - $\quad$ - 269

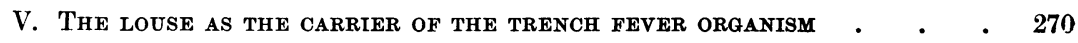

1. Is the organism transferred to man through the proboscis of the louse? $\mathbf{2 7 0}$

2. By the excreta of infected lice? . . . . . . . . 271

3. By the excreta of clean lice? . . . . . . . . . $\quad$. 271

4. By the feeding of clean lice through a layer of infected excreta? . $\quad$ - 272

5. By the crushing of bodies of infected lice? . . . . . . $\quad$. 272

6. Do lice fed on a case within 12 hours of onset of disease become infective? 272

7. Do lice fed on an afebrile case become infective? $\quad . \quad$. $\quad . \quad 273$

8. At what temperature do lice require to be kept between feedings? $\quad$ - 273

9. What time elapses between an infected feed and the passage of infective $\mathbf{2 7 3}$ louse excreta? . . . . . . . . . . . . . $\quad$. 274

10. What percentage of lice become infective? . . . . . . . $\quad$. 274

11. Hereditary transmission of the organism in the louse . $\quad . \quad$. $\quad 275$

12. Does Pediculus capitis convey the organism? . . . . . . $\quad$. 275

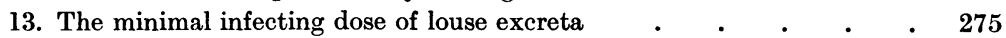

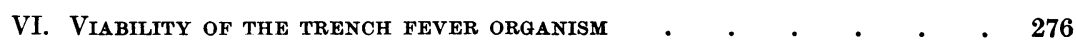

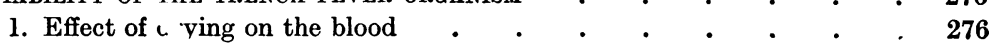

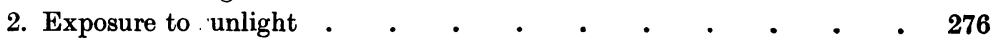


3. Effect of distilled water
PAGE

4. How long do louse excreta remain infective? $\quad$ • $\quad$ • $\quad$ • $\quad$ - 277

5. At what temperature is the organism killed: $(a)$ by dry heat, $(b)$ by moist heat? . . . . . . . . . . . . 277

6. Effect of ultra-violet rays on the organism . $\quad . \quad$. $\quad . \quad$. $\quad 278$

7. Effect of antiseptics and other chemical substances $\quad$ • $\quad . \quad$ • $\quad$ • 278

VII. ARe any of the laboratory animals SUSCePtible to trench FEVER $\quad 279$

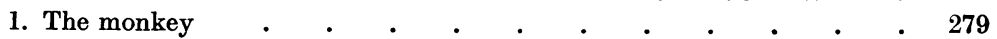

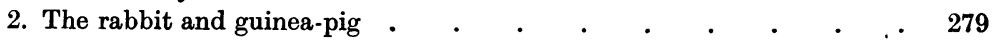

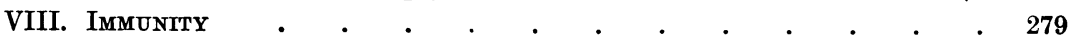

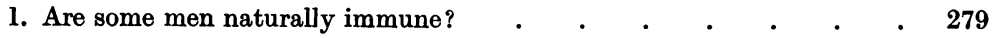

2. Does an attack of the disease confer immunity? . $\quad$. $\quad$ - $\quad 280$

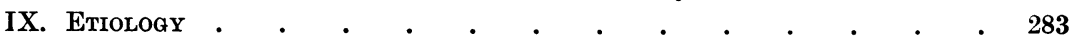

1. Rickettsia-like organisms found in the excreta of infected lice $\quad$. $\quad 283$

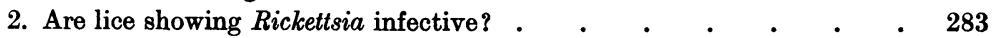

3. How early in the disease can a patient cause lice fed on him to show Rickettsia? . . . . . . . . . . . . 284

X. To ascertain IF the TRENCh FEVER ORGANiSM CAN BE TRANSMitTed BY OTHER BLOOD-SUCKING INSECTS . . . . . . . . 284

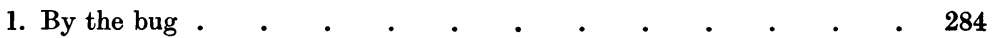

XI. Cultivation of the trench Fever organism in artificial media . $\quad 285$

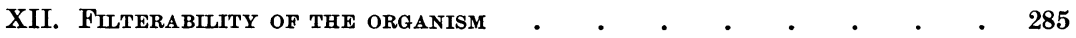

1. When present in the blood . . . . . . . . $\quad 285$

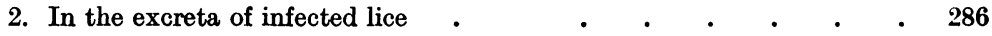

\section{INTRODUCTION.}

THE chief object of this report is to place on record the remainder of the experimental work carried out under the direction of the War Office Trench Fever Investigation Committee by Major Byam and his co-workers at the New End Military Hospital, Hampstead, during part of 1917 and the two following years.

This Committee was formed in November 1917 by Lieut.-General Sir Alfred Keogh, G.C.B., the Director General of the Army Medical Services, for the purpose of investigating Trench Fever with a view to the discovery of its causation, mode of spread and prevention.

The Committee consisted of:

Major General Sir David Bruce, K.C.B., F.R.S., A.M.S., Chairman.

J. A. Arkwright, Esq., M.A., M.D., D.Sc., Lister Institute.

A. W. Bacot, Esq., F.E.S., Lister Institute.

J. E. Barnard, Esq., P.R.M.S.

Major W. Bуaм, R.A.M.C.

Professor John Eyre, M.D.

Sir W. M. Fletcher, K.B.E., F.R.S.

Lieut.-Colonel H. French, C.B.E., R.A.M.C. (Temp.)

Lieut.-Colonel D. HaRvey, C.M.G., R.A.M.C.

The late Professor H. Plimmer, F.R.S. and Lieut. A. F. Hird, General List (Temp.), Secretary.

Lieut-Colonel Ledingham, C.M.G., F.R.S., Lister Institute, after his return from active service, also served on the Committee. 
The Committee held their first meeting on the 12th Nov. 1917, when Major Byam stated that he already had a number of officers working on this subject under his direction at the Hampstead Military Hospital.

The names of the working party were:

Major W. Byam, R.A.M.C.

Captain J. H. CARROLL, U.S.R.

Captain J. H. Churchill, R.A.M.C. (T.)

Captain Lyn Dimond, R.A.M.C.

Captain V. E. Sorapure, R.A.M.C.

Captain R. M. Wilson, R.A.M.C.

Captain Peacock, R.A.M.C. (T.), Entomologist.

Lieut. LL. Lloyd, R.A.M.C. (T.) was appointed at the beginning of 1918 in

Captain Peacock's place on the latter's transfer to France.

In addition to the working party at Hampstead, Messrs Arkwright, Bacot, and Ledingham of the Lister Institute, members of the War Office Committee, took a prominent part in the research, especially in regard to the part played by the louse in the spread of the disease and the relation of the so-called Rickettsia-bodies to Trench Fever.

Mr J. E. Barnard, another member of the Committee, also gave conspicuous aid to the working party in the microscopic examination and filtration of the blood and the action of ultra-violet rays on the virus.

Lieut.-Colonel French deserves honorary mention as it was by his instrumentality that the first volunteers were found. Without the volunteers the main object of the work could not have been attained.

The War Office Committee met as a rule at weekly intervals. Its last meeting, the 83rd, was held on January 19th, 1920, when Colonel D. Harvey, the acting chairman, announced that the Army Council had dissolved the Committee.

Major Byam and his co-workers have already described the larger part of the results of their work; first in a paper read before the Royal Society of Tropical Medicine and Hygiene on May 17th, 1918, and later in book form, entitled Trench Fever, Oxford Medical Publications, which appeared in 1919.

Lieut. Lloyd the entomologist also brought out a book, called Lice and their Menace to Man in the same year, and by the same publishers, which included some of the work done at Hampstead, especially in the chapter on the migration of body lice from trench fever cases to healthy men.

Other publications have also appeared which arose out of this work: The Nerrous Hearl, by Captains R. M. Wilson and John H. Carroll; "The Association of Rickettsia with Trench Fever," by J. A. Arkwright, A. Bacot and F. Martin Duncan, Journal of Hygiene, vol. xvirr. no. 1, April 15, 1919; "Agglutination Experiments with Trench Fever Rickettsia," by J. C. .G. Ledingham, The Lancet, vol. I. p. 1264, 1920.

About the same time that this investigation was being begun in England, the American Red Cross were organising a similar research in France. 
In October 1917 at the first meeting of the Medical Research Committee of the American Red Cross in Paris, Major R. P. Strong recommended that a research into Trench Fever should be undertaken. He stated that after several months' study of the problems relating to the prevention of infectious diseases occurring in the Allied Armies on the Western Front it became evident that the subject of the method of transmission of Trench Fever was one of the most important for investigation in connection with the loss of man-power in the fighting forces.

At the next meeting in November 1917 this was agreed to, and a Trench Fever Committee under the chairmanship of Major Strong was formed. In co-operation with the Medical Investigation Committee of the British Expeditionary Force the research was organised and experiments begun on February 4th, 1918. The members of this Commission were eight in number, seven Americans and one Englishman, Lieut. A. D. Peacock, R.A.M.C., as entomologist. In less than six months the investigation was completed and the Report in the hands of the printers. This is entitled, Trench Fever Report of Commission, Medical Research Committee, Americar Red Cross, Oxford University Press, 1918, and was edited by Major Strong. This report represents an extraordinary able piece of research, and shows the great advantage in rapidity to be gained from team work.

It may be considered that there was now no necessity for the War Office Trench Fever Committee to continue its work in London. It must be remembered however that Major Byam and his team had been working at the subject for some time before the War Office Committee was formed, also that it was important that the work should be confirmed in England at a distance from the front line in France where cases of the disease were numerous. Further as all the experimental work had to be performed on man, the number was necessarily limited and controls inadequate. The work of one Commission would often therefore serve to supplement the work of the other and lessen to some extent these disabilities. The result of the work of the two Commissions justifies this, as the conclusions arrived at are by no means identical. For example the American Commission came to the conclusion that the organism causing the disease is a resistant filterable virus; whereas the British concluded that it was neither filterable nor ultra-microscopic, which the word filterable is usually supposed to imply, but was in fact a species of Rickettsia related to the organism found in typhus fever. Again the American Commission states that the usual manner of infection is by the bite of the louse. The British Commission on the other hand is of opinion that infection by the bite is quite exceptional and that by far the commonest method is by infection of scratches or other small wounds, with the excreta of the louse.

Moreover the American Commission had for their main object the demonstration and experimental proof of the mode of transmission of the disease, for the practical purpose of preventing the loss of man-power at the front; the object of the English Committee was to make a complete investigation 
of the disease from every point of view; and it is to be regretted that the exigencies of the Service caused the Army Council to close down the Committee before this was by any means accomplished.

It may be thought that as Trench Fever disappeared at the conclusion of the war, it is not necessary to place these remaining experiments on record. On the other hand it would appear to be all the more important since there will probably be no further opportunity of studying the disease until the next European war. Again as most of these experiments were carried out on man himself, and a good deal of expense incurred, it would appear to be unwise to allow any of the knowledge gained to lapse.

This Report then is merely meant to place on record the remaining experiments carried out at the Trench Fever Hospital, Hampstead, by Major Byam, and his colleagues. No attempt will be made to describe the clinical features, geographical distribution, pathology, diagnosis or treatment of the disease. These are all dealt with in the reports mentioned above, and in numerous other papers and need not be repeated here.

It may be recorded here that several of the staff at Hampstead became infected with Trench Fever in the course of the investigation. Captain Carroll, one of the medical officers, and Sister Pullen, one of the nursing staff, became infected, but the exact method of infection was not ascertained.

Sergeants Clifford and Heylock, laboratory assistants, were also attacked by the disease; both frequently handled the infected boxes of lice and collected the louse excreta.

Dr Arkwright and Mr Bacot of the Lister Institute also became infected, probably through the bites or excreta of infected lice.

In conclusion the Committee would wish to express their most sincere thanks and admiration for the excellent work done by Major Byam and his team of workers at Hampstead. They worked without sparing themselves from the beginning to the end of the investigation with the greatest zeal, intelligence and enthusiasm and have made a notable advance in our knowledge of the infectious diseases.

The Committee would also desire to convey their heartiest thanks to the nursing staff of New End Hospital. The Sisters took the greatest possible interest in the investigation and aided and co-operated with the medical workers in every possible way.

Without the volunteers nothing could have been achieved. These men, unable through age or other infirmities to go to the front, bravely did their bit for the sake of their comrades in the trenches, by allowing themselves to be inoculated with an often tedious and painful disease. The Army owes them the deepest gratitude.

The Committee would also beg to acknowledge the constant assistance and encouragement they received from Lieut.-General Sir Alfred Keogh, G.C.B., Director General of the Army Medical Services and his successor Lieut.General Sir T. H. Goodwin, K.C.B. 
The Committee also beg to place on record the generosity of the Lister Institute of Preventive Medicine. Not only did this Institute provide several workers to help in the investigation, but it also financed the experimental work to the extent of $£ 2300$. Without this assistance it is difficult to know how the work could have been carried out.

As it will not be possible on account of expense, to print the individual experiments in full, we beg to inform future workers on Trencb Fever, that all the original papers, temperature charts, case sheets, etc. in connection with this investigation are preserved at the Lister Institute, Chelsea Gardens, London, and may be consulted there.

\section{IN WHAT TISSUES OF THE BODY IS THE ORGANISM OF TRENCH FEVER FOUND?}

\section{Whole blood.}

In the investigation of a disease one of the first things is to find out if there is any infecting organism present. This was first done by English workers in the case of Trench Fever by McNee, Brunt and Renshaw at the beginning of 1916. They succeeded it transferring the disease to healthy men by the injection of the blood of Trench Fever cases. This observation was confirmed by the American Commission in 1918. McNee and his colleagues carried out seven experiments with whole blood. These were all positive. The Americans had twelve positive and one negative result. The following table gives the experiments also made by the War Office Committee to confirm McNee's results.

\begin{tabular}{|c|c|c|c|c|c|c|}
\hline $\begin{array}{c}\text { Exp. } \\
\text { no. }\end{array}$ & $\begin{array}{c}\text { Amount } \\
\text { of blood } \\
\text { injected } \\
\text { in c.c. }\end{array}$ & $\begin{array}{c}\text { Day } \\
\text { of } \\
\text { disease }\end{array}$ & $\begin{array}{c}\text { Treatment } \\
\text { of } \\
\text { blood }\end{array}$ & $\begin{array}{l}\text { Interval, } \\
\text { in minutes, } \\
\text { between } \\
\text { collection and } \\
\text { experiment }\end{array}$ & Route & Result \\
\hline 3 & 5 & 24 & Citrated & 8 & Vein & + \\
\hline 4 & 5 & 9 & , & 5 & Vein & + \\
\hline 7 & 5 & 3 & , & $\frac{1}{2}$ & Intra-muscular & - \\
\hline 15 & 5 & 2 & " & 1 & Vein & + \\
\hline 19 & 5 & 51 & $"$ & 1 & Intra-muscular & + \\
\hline 36 & 5 & 2 & $"$ & 1 & Vein & + \\
\hline 135 & 5 & 1 & " & 1 & Vein & + \\
\hline 139 & 5 & 1 & , & 3 & Subcutaneous & - \\
\hline 174 & 10 & 5 & ", & 2 & Intra-muscular & - \\
\hline
\end{tabular}

In the above nine experiments it is seen that six are positive and three negative. On examining the protocols of the three negative experiments none of them are found to be satisfactory. The blood used in No. 139 was taken from a very mild case, on the first day of the attack: that used in No. 174 was from a case whose blood gave negative results in three experiments and for some unknown reason the blood seems to have been non-infective on the day of withdrawal. It will be noted that the three negative experiments follow on intra-muscular or subcutaneous injections; all those injected intravenously are positive. 
Conclusion. It is abundantly proved that the Trench Fever organism is present in the "whole blood" of Trench Fever cases and that therefore it will be found in all the tissues of the body.

\section{THE RELATION OF THE ORGANISM TO THE BLOOD.}

\section{Blood plasma.}

After it was proved that the whole blood of Trench Fever patients contains the organism, experiments were made to discover in what part of the bloodplasma or corpuscles - the organism was located, in other words is the parasite intra-corpuscular or extra-corpuscular.

Table II.

\begin{tabular}{|c|c|c|c|c|c|c|}
\hline $\begin{array}{l}\text { Exp. } \\
\text { no. }\end{array}$ & $\begin{array}{c}\text { Amount } \\
\text { of blood } \\
\text { injected } \\
\text { in c.c. }\end{array}$ & $\begin{array}{c}\text { Day } \\
\text { of } \\
\text { disease }\end{array}$ & $\begin{array}{c}\text { Treatment } \\
\text { of } \\
\text { blood }\end{array}$ & $\begin{array}{l}\text { Interval } \\
\text { between } \\
\text { collection } \\
\text { and } \\
\text { experiment }\end{array}$ & Route & Result \\
\hline 203 & 11 & 6 & $\begin{array}{l}\text { Citrated and } \\
\text { centrifuged }\end{array}$ & $\begin{array}{l}3 \text { hours } \\
51 \text { mins. }\end{array}$ & Vein & + \\
\hline 215 & 5 & 4 & Citrated & 8 hours & Vein & - \\
\hline
\end{tabular}

In the first place it was attempted to remove the corpuscles from the citrated blood by the centrifuge, and so to separate out the blood plasma.

McNee reports one such experiment with blood plasma which gave a positive result.

The American Commission made five experiments on similar lines which were all successful.

Only two experiments were made by the War Office Trench Fever Committee, the first was positive, the second negative. The second was done as a control to a filtration experiment and consisted in the withdrawal of 60 c.c. of blood from a Trench Fever patient. This blood was added to 300 c.c. citrate solution and allowed to sediment by gravity. 5 c.c. of the upper layer of the diluted plasma was pipetted off and injected. This is a very doubtful experiment and may be ignored.

Conclusion. In seven experiments with unfiltered plasma the result was positive. It may therefore be concluded that probably the organism of Trench Fever is to be found free in the fluid part of the blood, that it is extra-corpuscular and not intra-corpuscular.

\section{Blood serum.}

Table III.
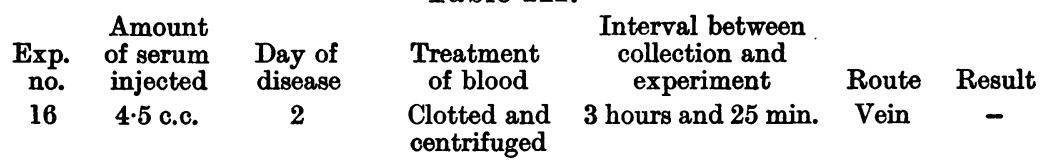

It would appear that when the blood is allowed to clot the micro-organisms of Trench Fever are entangled in the fibrin and so disappear from the clear serum which is separated. 
McNee and his colleagues made two experiments with serum one of which was negative and one positive. The serum in the positive case was haemoglobin tinted, this condition being due according to McNee to faulty technique.

The American Commission also made an experiment with serum and failed to transmit the disease.

The one experiment made by the War Office Committee is given above.

Conclusion. When the blood of Trench Fever cases was allowed to clot naturally the separated serum in three cases was found to be sterile. Hence it may be inferred that when blood is allowed to clot the Trench Fever organisms are entangled in the fibrin and do not appear in the clear serum. Another conclusion might be that the virus is contained in the corpuscles and so disappears from the serum.

\section{Blood corpuscles.}

No attempt was made by the War Office Committee to ascertain if the micro-organism of Trench Fever is an intra-corpuscular parasite.

McNee, Renshaw and Brunt report two experiments with washed corpuscles; one negative and one positive. They are of opinion that their results point to the virus being contained within the blood corpuscles themselves; whether leucocytes or red cells.

The American Commission states that of four volunteers injected with washed blood cells, three developed the disease. The average incubation period was considerably prolonged over that obtained with the injection of whole plasma from the same cases and this they consider suggests that the virus was not in the blood cells, but that it existed mixed with them and had not been completely separated by the three washings.

Conclusion. The evidence on the whole appears to be more in favour of the virus being extra-corpuscular than intra-corpuscular, but it must be confessed that the proof of this is not very satisfactory. If the organism could only be demonstrated in the blood by means of the microscope this question would be cleared up, but this has not been done up to the present.

\section{Laked whole blood.}

Table IV.

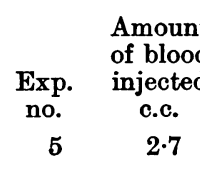

\begin{tabular}{|c|c|c|c|}
\hline Treatment of blood & $\begin{array}{l}\text { Interval between } \\
\text { collection and } \\
\text { experiment }\end{array}$ & Route & Result \\
\hline $\begin{array}{l}10 \text { c.c. blood added } \\
\text { to } 10 \text { c.c. citrate } \\
\text { of soda and then } \\
\text { added to } 170 \mathrm{c.c} \\
\text { of Aq. Dis. } 20 \mathrm{c.c} \\
\text { of N.S. } 10 \text { times } \\
\text { normal strength } \\
\text { added to above }\end{array}$ & $1 \frac{3}{4}$ hours & Vein & - \\
\hline $\begin{array}{l}\text { Laked in } 20 \text { c.c. Aq. } \\
\text { Dis. }\end{array}$ & 17 mins. & Vein & + \\
\hline
\end{tabular}


Experiments on the effect of laking infective Trench Fever blood were made in connection with filtration experiments. In the case of Exp. 5 it would appear that the addition of a large quantity of distilled water for the purpose of laking the blood had rendered the blood non-infective. That the blood was originally infective is shown in Exp. 4. In the second experiment when 5 c.c. of blood was laked by a smaller quantity of distilled water and kept for a shorter time the result was positive.

The number of experiments is too small to justify any conclusion.

\section{Minimal quantity of whole blood required.}

\begin{tabular}{|c|c|c|c|c|c|c|}
\hline $\begin{array}{l}\text { Exp. } \\
\text { no. }\end{array}$ & $\begin{array}{l}\text { Amount } \\
\text { of blood } \\
\text { injected } \\
\text { c.c. }\end{array}$ & $\begin{array}{l}\text { Day of } \\
\text { disease }\end{array}$ & $\begin{array}{l}\text { Treatment } \\
\text { of blood }\end{array}$ & $\begin{array}{l}\text { Interval between } \\
\text { collection and } \\
\text { experiment } \\
\text { mins. }\end{array}$ & Route & Result \\
\hline 87 & 0.5 & 1 & Citrated & 1 & Vein & + \\
\hline 124 & $0 \cdot 1$ & 1 & Citrated & 1 & Vein & - \\
\hline 173 & $0 \cdot 1$ & 5 & Citrated & 2 & Vein & - \\
\hline
\end{tabular}

The last experiment (No. 173) is not satisfactory. When tested later for natural immunity the case also failed to react, although a large dose of virus was used.

From the above experiments it would appear that 0.5 c.c. of blood in one instance was sufficient to transfer Trench Fever to a healthy man, but that $0 \cdot 1$ c.c. was not enough.

It has been shown that the intra-venous method of transferring the blood from cases of Trench Fever to healthy men seems to be more successful than the intra-muscular or subcutaneous. An attempt was made to infect by inoculation of infective blood into a scarified area of the skin.

\section{Inoculation of scarified area of skin with whole blood.}

Table VI.

$\begin{array}{ccc}\text { Exp. } & \begin{array}{c}\text { Amount of } \\ \text { blood used } \\ \text { c.c. }\end{array} & \begin{array}{c}\text { Day of } \\ \text { disease }\end{array} \\ 38 & 10 & 2 \\ 44 & 1 & 2 \\ 88 & 0.5 & 1\end{array}$

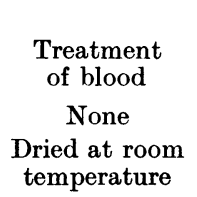

Citrated

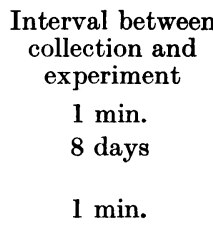

Route Result.

Skin -

Skin

Skin

In the above three experiments the attempt to transfer Trench Fever by the application of whole infected blood to the scarified skin was unsuccessful.

In Exps. 38 and 88 the blood was proved to be infective by other experiments carried out at the same time.

It will appear a plausible deduction from these experiments that either the organism of Trench Fever is very few and far between in infective blood, or the conditions are such as to render it less easily absorbed through the scarified skin. It will be found later that a very small quantity of infective 
louse excreta rubbed into a scarified area of the skin almost always gives rise to the disease.

7. To ascertain when blood of trench fever cases becomes infective.

Table VII.

\begin{tabular}{|c|c|c|c|c|c|c|}
\hline $\begin{array}{l}\text { Exp. } \\
\text { no. }\end{array}$ & $\begin{array}{l}\text { Amount } \\
\text { of blood } \\
\text { injected }\end{array}$ & $\begin{array}{l}\text { Day of } \\
\text { disease }\end{array}$ & $\begin{array}{l}\text { Treatment } \\
\text { of blood }\end{array}$ & $\begin{array}{l}\text { Interval between } \\
\text { collection and } \\
\text { experiment }\end{array}$ & Route & Result \\
\hline 188 & 1 c.c. & Under $12 \mathrm{hrs}$. & Citrated & At once & Vein & - \\
\hline
\end{tabular}

Only one experiment was made with blood taken five hours after the first rise of temperature. From other evidence it would appear that the microorganisms of Trench Fever are very scarce in the peripheral blood during the first twelve hours of the onset of the fever.

\section{How long does the blood of trench fever patients remain infective?} Table VIII.

\begin{tabular}{|c|c|c|c|c|c|}
\hline $\begin{array}{l}\text { Exp. } \\
\text { no. }\end{array}$ & Nature of experiment & $\begin{array}{l}\text { Day of } \\
\text { disease }\end{array}$ & Inoculation & Route & Result \\
\hline 72 & Lice fed on old chronic case & 298 & $\begin{array}{l}\text { Excreta rubbed into } \\
\text { scarified area of skin }\end{array}$ & Skin & + \\
\hline 92 & ", & 298 & $\because$ & Skin & - \\
\hline 93 & , & 116 & " & Skin & - \\
\hline 181 & , & 443 & 40 mg. excreta in 4 c.c. N.S. & Subcut. & + \\
\hline 184 & " & 182 & $8 \mathrm{mg}$. excreta in 1 c.c. N.S. & Subcut. & - \\
\hline 212 & , & 175 & 10 mg. excreta in 5 c.c. N.S. & Subcut. & - \\
\hline
\end{tabular}

This is important from the point of view of the spread of the infection. No experiments were made to answer the question by the direct injection of blood from old chronic cases into healthy volunteers. The method used was to feed lice on the old cases and afterwards inoculate the excreta of these lice into healthy individuals. This was found to be a much more certain method of setting up the disease than by the direct transference of blood, due probably to the multiplication of the virus in the intestine of the louse.

From the above six experiments it will be seen that cases of Trench Fever may retain the power of infecting lice fed on them up to at least 443 days after the onset of the disease. That all cases do not retain this infectivity is evident from the fact that four of the six experiments are negative.

\section{Microscopical examination of the blood.}

It may be said at the outset that up to the present no organism has been found in the blood, organs, urine or faeces of cases of Trench Fever which can undoubtedly be considered to be the cause of the disease. It is unnecessary to give an account here of the various organisms which have been described, as a summary has already been given by the American Red Cross Commission in their Report.

Mr Barnard reported to the War Office Committee that the examination of trench fever blood under dark ground illumination showed the presence of 
minute granules which he had been unable to find in normal blood. These granules fluctuated in number from day to day reaching a maximum shortly before the rise in temperature. He considered these particles to measure about $0 \cdot 1$ micron in size and therefore to be much smaller than the Rickettsia-bodies found in the louse. This difference in apparent size may possibly have been due to the difference in mode of preparation; unstained and floating in a layer of blood in the one case, dried and stained in the other.

Mr Bacot states that, in the section of the American Red Cross Committee's Report dealing with the absence of visible micro-organisms in the blood and plasma of patients, it is admitted that a few bodies resembling the diplobacilli described by the German investigators as the cause of the disease were occasionally encountered in stained specimens of the blood and plasma but the report goes on to state that the American workers could obtain no definite evidence that these bore any etiological relationship to the disease.

Bacot adds that subsequent work in England and on the Continent has resulted in a fairly general acceptance of the fact that the presence of such bodies (Rickettsia), found in infected lice, is related to the power of the insect to convey the disease. The difficulty, however, of diagnosing the disease from the presence of a few such forms in blood films has not been surmounted because the scarcity of the bodies renders the confusion of artefacts of similar appearance possible.

Though workers on the Continent appear to be satisfied that they can use this method of diagnosing the disease with some certainty, American and English workers have up to the present been unable to accept such evidence with any confidence.

\section{HOW DOES THE ORGANISM OF TRENCH FEVER LEAVE THE BODY?}

\section{In the sputum and saliva.}

No experiments were made in England on this point. Three experiments to determine the infectivity of the sputum and saliva were made by the American Commission. The saliva and sputum were centrifuged and the sediment dried at $30^{\circ} \mathrm{C}$. The sediment was then rubbed into scarified areas of the skin of three volunteers. Two of the experiments remained negative; one was positive.

The American Commission concluded that the sputum with the saliva mixed in it is sometimes infective.

It appears to us that the experiments are too few in number to justify any conclusion being drawn.

\section{In the urine.}

It would be surprising if the micro-organism of Trench Fever did not find its way out of the blood into the urine at some period or other of the disease. The three experiments made by the English workers are all negative. The 
urine was taken at three different periods as will be seen from the following Table.

Table IX.

$\begin{array}{rcc}\begin{array}{c}\text { Exp. } \\ \text { no. }\end{array} & \begin{array}{c}\text { Amount of urine } \\ 69\end{array} & \begin{array}{c}\text { Day of } \\ \text { disease }\end{array} \\ 78 & \begin{array}{c}\text { c.c. morning and } \\ \text { evening daily }\end{array} & 19 \text { to } 25 \\ 159 & \begin{array}{c}\text { c.c. morning and } \\ \text { evening daily }\end{array} & 1 \text { to } 10 \\ & \begin{array}{c}\text { 20 c.c. daily from } \\ \text { two patients }\end{array} & 11 \text { to } 20\end{array}$

\begin{tabular}{|c|c|c|c|}
\hline \multicolumn{4}{|c|}{$\begin{array}{l}\text { Interval between } \\
\text { collection and }\end{array}$} \\
\hline Treatment of urine & experiment & Route & Result \\
\hline $\begin{array}{c}\text { Centrifuged and } \\
\text { deposit dried at } 37^{\circ} \mathrm{C} .\end{array}$ & 36 hours & Skin & - \\
\hline $\begin{array}{c}\text { Centrifuged and } \\
\text { deposit dried at } 37^{\circ} \mathrm{C} .\end{array}$ & 3 days & Skin & - \\
\hline $\begin{array}{c}\text { Centrifuged and } \\
\text { deposit dried at } 37^{\circ} \mathrm{C} .\end{array}$ & 12 days & Skin & - \\
\hline
\end{tabular}

In all three cases the urine was centrifuged and dried at $37^{\circ} \mathrm{C}$.

The American Commission were more successful. Eight experiments were made to determine the infectivity of the urine, of these five were positive.

Conclusion. From the results of the American Commission's experiments it may be concluded that the urine of Trench Fever cases does frequently contain the organism of the disease. It is curious that none of the English experiments showed a positive result.

\section{In the faeces.}

No experiments were made by the English Committee.

Three experiments were carried out by the American Commission. A portion of the faeces taken from Trench Fever cases was smeared in thin layers in Petri dishes and dried in the open air; all the specimens were mixed and ground in a mortar. A small amount of the resulting powder was then moistened with normal saline solution and made into a paste. This was then rubbed into scarified areas of the skin of the volunteers. All the experiments were negative.

The American Commission conclude from these experiments that there is no evidence that the faeces are infective in Trench Fever.

It will be shown later that infection probably does not take place by way of the mouth in food or drink, or by way of the mucous membrane of the nose. If this is true then the importance of the infectivity of the saliva, sputum, urine or faeces is robbed of much of its significance.

\section{HOW DOES THE ORGANISM OF TRENCH FEVER ENTER THE BODY?}

1. By the mouth or nasal passages.

Table X.

\begin{tabular}{|c|c|c|c|c|c|c|}
\hline $\begin{array}{c}\text { Exp. } \\
\text { no. }\end{array}$ & \multicolumn{3}{|c|}{ Nature of experiment } & $\begin{array}{l}\text { No. of } \\
\text { feeds }\end{array}$ & Route & Result \\
\hline 13 & \multicolumn{3}{|c|}{ Excreta of lice given by the mouth and by inhalation } & 15 & $\begin{array}{l}\text { Mouth } \\
\text { and nose }\end{array}$ & - \\
\hline 14 & $"$ & ", & " & 9 & $\begin{array}{l}\text { Mouth } \\
\text { and nose }\end{array}$ & - \\
\hline 120 & \multicolumn{3}{|c|}{ Only by the mouth } & 6 & Mouth & - \\
\hline
\end{tabular}

In these few experiments large quantities of infective material were given by the mouth and nose with negative results. From this it may be concluded Journ. of Hyg. xx 
that the contamination of food by the urine, sputum or saliva of affected persons or by the excreta of infected lice does not constitute a danger.

In other words the virus of Trench Fever is not conveyed from the sick to the healthy by way of the mouth in eating or by way of the nose in breathing.

\section{Through the conjunctiva and other mucous membranes.}

Table XI.

\begin{tabular}{rccccc}
\multicolumn{2}{c}{ Exp. no. Amount of excreta used } & No. of inoculations & Age of excreta & Route & Result \\
77 & From 500 lice & 3 & 24 days & Conjunctiva & + \\
119 & From 400 lice & 1 & 15 days & , & + \\
205 & & 1 & 96 days & Urethra & - \\
207 & $10 \mathrm{mgm}$. & 3 & 93 days & " & -
\end{tabular}

It is curious that the sniffing up the nose of the infected excreta of lice did not give rise to infection, whereas the placing of the same material in the conjunctival sac did give rise to positive results in two cases.

The attempt to infect by way of the urethra was unsuccessful.

It may be concluded that the micro-organism of Trench Fever does not enter the body by way of the mouth in the act of eating or drinking, by the nose in breathing, or by the contact of infective material with healthy skin. It would appear then to be probable that, as it is found constantly in the blood, the mode of infection will be by a blood sucking insect.

\section{THE LOUSE AS THE CARRIER OF THE TRENCH FEVER ORGANISM.}

That the louse is the carrier of the organism of Trench Fever has now been abundantly proved. It is unnecessary to repeat the history of this discovery since it is given by Major Byam and his colleagues in their report, and by the American Red Cross Commission. Suffice it to say that as early as July 1916 Hunt and McNee write that they think sufficient evidence has now been obtained that the body louse is the parasite concerned although absolute proof is lacking, as they had been unable to carry out actual transmission experiments.

To the War Office Trench Fever Committee is due the honour of having been the first to demonstrate by experiment the part played by the louse in the transmission of Trench Fever, the first successful result having been obtained on the 14th Feb., 1918. On the 9th March the American Commission also announced positive results.

There is some doubt as to whether the disease is transferred from the louse to man in the act of biting, or by the inoculation of the excreta of the louse into abraded surfaces. Table XII shows the results following the bite of the louse.

From a consideration of Tables XII-XIV it is manifest that infection through the proboscis of the louse in the act of biting rarely happens and only after a long time. The incubation period in the four cases which gave a positive 
1. Is the organism transferred through the proboscis of the louse?

Table XII.

\begin{tabular}{|c|c|c|c|c|c|}
\hline $\begin{array}{l}\text { Exp. } \\
\text { no. }\end{array}$ & $\begin{array}{l}\text { No. of days over } \\
\text { which feeding } \\
\text { extended }\end{array}$ & $\begin{array}{l}\text { Number } \\
\text { of bites } \\
\text { estimated }\end{array}$ & $\begin{array}{l}\text { Incubation } \\
\text { in days }\end{array}$ & Result & Remarks \\
\hline 1 & 35 & 9,518 & $\ldots$ & - & \\
\hline 2 & 41 & 13,224 & $\ldots$ & - & \\
\hline 40 & 17 & 4,945 & $\ldots$ & - & \\
\hline 47 & 14 & 23,821 & $\ldots$ & - & Lice let loose excreta not removed \\
\hline 48 & 14 & 25,609 & 14 & + & $\begin{array}{l}\text { Fed through chiffon, excreta wiped } \\
\text { off with cotton wool }\end{array}$ \\
\hline 50 & 14 & 21,908 & ... & - & \\
\hline 67 & 5 & 7,520 & $\ldots$ & - & $\begin{array}{l}\text { Skin washed with abs. alcohol after } \\
\text { feed }\end{array}$ \\
\hline 68 & 32 & 40,580 & 35 & + & $\begin{array}{l}\text { Skin washed with abs. alcohol after } \\
\text { feed }\end{array}$ \\
\hline 149 & 26 & $\ldots$ & $\ldots$ & - & Skin washed lysol no scratching \\
\hline 176 & 18 & 14,600 & 18 & + & Skin washed lysol \\
\hline 188 & 43 & 6,136 & 44 & + & $\begin{array}{l}\text { Fed through chiffon, washed lysol; } \\
\text { scratched himself }\end{array}$ \\
\hline
\end{tabular}

2. By the excreta of infected lice.

Table XIII.

\begin{tabular}{|c|c|c|}
\hline $\begin{array}{c}\text { Exp. } \\
\text { no. }\end{array}$ & $\begin{array}{c}\text { Amount of } \\
\text { excreta }\end{array}$ & Day of disease \\
\hline 8 & 576 lice & Various \\
\hline 10 & $\ldots$ & , \\
\hline 11 & ... & " \\
\hline 12 & ... & $"$ \\
\hline 32 & $\ldots$ & , \\
\hline 56 & $\ldots$ & 8 to 16 \\
\hline 64 & $\ldots$ & 27 to 28 \\
\hline 72 & 300 lice & 298 to 339 \\
\hline 81 & 500 lice & 27 to 28 \\
\hline 92 & 300 lice & 298 to 339 \\
\hline 93 & 250 lice & 116 to 118 \\
\hline 96 & 2 mgm. & 9 \\
\hline 97 & $0.1 \mathrm{mgm}$. & 9 \\
\hline 102 & 0.05, & 9 \\
\hline 109 & $0.1 \quad$, & 9 \\
\hline 127 & $1 \quad$ & 2 to 25 \\
\hline 130 & 2 & 9 \\
\hline 138 & $"$ & 3 to 14 \\
\hline 148 & , & Various \\
\hline 152 & 40 & , \\
\hline 172 & , & , \\
\hline 182 & , & 16 to 18 \\
\hline 198 & 10 & Various \\
\hline 208 & ... & ", \\
\hline 214 & $8 \quad$ " & , \\
\hline
\end{tabular}

\begin{tabular}{|c|c|c|c|c|}
\hline \multicolumn{2}{|c|}{$\begin{array}{l}\text { Treatment of } \\
\text { excreta }\end{array}$} & $\begin{array}{l}\text { Interval between } \\
\text { collection and } \\
\text { experiment }\end{array}$ & Route & Result \\
\hline & & 6 hours & Skin & + \\
\hline & & 15 minutes & ", & + \\
\hline & & ” & , & + \\
\hline & & 1 hour and 15 mins. & ", & + \\
\hline & & 3 hours & , & + \\
\hline & & 27 days & " & + \\
\hline & & 1 hour & , & + \\
\hline & & 1 day & , & + \\
\hline & & $\cdots$ & " & + \\
\hline & & 21 days & , & - \\
\hline & & 19, & , & - \\
\hline In 1 & N.S. & ... & Subcut. & + \\
\hline & & $\cdots$ & ", & + \\
\hline & & $\cdots$ & " & - \\
\hline & & ... & " & - \\
\hline & & 29 days & , & + \\
\hline & & 70 & ", & - \\
\hline In 1.5 & c. N.S. & $86 \quad$ " & , & + \\
\hline In $1 \mathrm{c}$ & N.S. & 1 to 74 days & , & + \\
\hline, 4 & , & 5 and more & 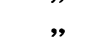 & + \\
\hline, 2 & , & $\ldots$ & , & + \\
\hline, 1 & , & 39 days & , & + \\
\hline, 2 & ", & $84 \quad$, & , & + \\
\hline & & 130, & ", & + \\
\hline In 1 & N.S. & ... & ", & + \\
\hline
\end{tabular}


3. By the excreta of clean lice.

Table XIV.

$\begin{array}{rccccc}\text { Exp. } & \begin{array}{c}\text { Amount of } \\ \text { excreta }\end{array} & \begin{array}{c}\text { Treatment } \\ \text { of excreta }\end{array} & \begin{array}{c}\text { Interval between } \\ \text { collection and } \\ \text { experiment }\end{array} & \text { Route } & \text { Result } \\ 17 & 300 \text { lice } & \text { None } & 17 \text { hours } & \text { Scarified skin } & - \\ 18 & \# & \# & \# & \# & - \\ 213 & \ldots & \# & 48, & , & -\end{array}$

result averaged 28 days. It is possible that this mode of infection never takes place at all as it must be difficult altogether to prevent the risk of infection through the skin by the excreta.

This is what would be expected as there is no evidence that the salivary glands of the louse are invaded as in malaria or trypanosomiasis and the danger of regurgitation of the intestinal contents into the proboscis seems remote.

On the other hand Table XIII shows how deadly a means of infection is provided by the excreta when brought in contact with an abraded surface of the skin. Practically in every case the disease is produced with the short average incubation period of $7 \cdot 7$ days.

Table XIV shows three control experiments with the excreta of clean lice; as will be seen all were negative.

\section{By the feeding of clean lice through a layer of infected excreta.}

It was thought by Major Byam and his colleagues that the small punctures made by the lice in the act of feeding might provide an entrance for the organism. Exp. 133 was devised to put this to the proof. Clean lice were made to feed on an area of skin covered with a thin moist layer of infected excreta. This was repeated on three occasions, but the result was negative.

5. To ascertain if the virus of trench fever can be transferred from louse to man by crushing the bodies of infected lice on an area of scarified skin.

\begin{tabular}{|c|c|c|c|c|c|}
\hline $\begin{array}{c}\text { Exp. } \\
\text { no. }\end{array}$ & $\begin{array}{c}\text { No. of } \\
\text { lice used }\end{array}$ & $\begin{array}{l}\text { Day of } \\
\text { disease }\end{array}$ & Treatment of lice & Route & Result \\
\hline 9 & 11 & $11-23$ & Crushed & Scarified skin & + \\
\hline 156 & 1 & $2-11$ & Emulsified in N.S. & " & - \\
\hline 157 & $\mathbf{1}$ & 2-11 & " & " & + \\
\hline 166 & 1 & $\cdots$ & " & " & - \\
\hline 167 & 1 & $\ldots$ & ", & ", & + \\
\hline
\end{tabular}

It is evident that in the scratching and rubbing which accompanies lousiness, lice must often be crushed and broken up. From the above experiments it is seen that on two occasions a single louse broken up in a drop of normal saline solution was capable of giving rise to the disease. 
6. To ascertain if lice fed on a trench fever case within 12 hours of the onset of the disease will become infective.

Table XVI.

\begin{tabular}{|c|c|c|c|c|c|c|c|}
\hline $\begin{array}{l}\text { Exp. } \\
\text { no. }\end{array}$ & $\begin{array}{c}\text { Amount of } \\
\text { excreta }\end{array}$ & $\begin{array}{l}\text { Day of } \\
\text { disease }\end{array}$ & $\begin{array}{l}\text { Treatment } \\
\text { of excreta }\end{array}$ & $\begin{array}{l}\text { Interval between } \\
\text { collection and } \\
\text { experiment }\end{array}$ & Route & Result & Remarks \\
\hline 144 & 70 lice & First & None & 12-18 days & $\begin{array}{l}\text { Scarified } \\
\text { skin }\end{array}$ & -1 & $\begin{array}{l}\text { Lice fed once within } 12 \\
\text { hrs. of rise of temp. }\end{array}$ \\
\hline 183 & $\begin{array}{l}80 \text { mgm. } \\
500 \text { lice }\end{array}$ & ", & 1.5 c.c. N.S. & 70 days & " & +1 & $\begin{array}{l}\text { Lice fed once within } 12 \\
\text { hrs. of rise of temp. }\end{array}$ \\
\hline 191 & $\begin{array}{l}20 \mathrm{mgm} . \\
1000 \text { lice }\end{array}$ & " & $"$ & 8-13 days & Subcut. & - & $\begin{array}{l}\text { Lice fed once within } 12 \\
\text { hrs. of rise of temp. }\end{array}$ \\
\hline
\end{tabular}

It will be remembered that in a former experiment (No. 188) 1 c.cm. of blood taken within five hours after the onset of the fever failed to give rise to the disease.

In the above three experiments lice were fed once within 12 hours after the onset. Afterwards their excreta was used for inoculation into healthy volunteers with one positive and two negative results.

It is probable then that the microorganisms of Trench Fever are present in the blood although in few numbers, at the beginning of the fever.

7. To ascertain if lice fed during an afebrile stage become infective.

Table XVII.

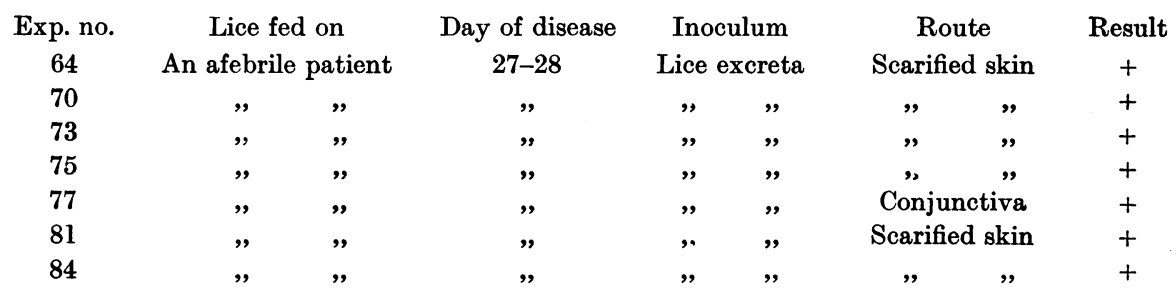

These experiments were made by feeding lice once on a Trench Fever case during an afebrile period, and afterwards using their excreta to infect healthy men. All gave a positive result, but fail in their object, since the patient again became febrile on the afternoon of the day on which the lice were fed.

8. To ascertain at what temperature lice require to be kept between feedings, in order that they may become infected.

Table XVIII.

$\begin{array}{ccccc}\text { Exp. no. } & \text { Amount of excreta } & \text { Temperature lice kept at } & \text { Route } & \text { Result } \\ 146 & \text { From } 200 \text { lice } & 30^{\circ} \mathrm{C} . & \text { Scarified skin } & - \\ 147 & " \# \text { " } & 12^{\circ}-17^{\circ} \mathrm{C} . & \# & - \\ 117 & 1 \mathrm{mgm} . & 27^{\circ} \mathrm{C} . & \# " \# & + \\ 118 & 1 \mathrm{mgm} . & 17^{\circ} \mathrm{C} . & \# "\end{array}$

These experiments are merely placed on record. From Exp. 118 it is evident that lice kept at room temperature between feedings are capable of 
carrying infection. The experiments are few in number and irregular in result but indicate that a temperature between $17^{\circ} \mathrm{C}$. and $27^{\circ} \mathrm{C}$. is adequate.

9. To ascertain what time elapses between an infecting feed and the infectivity of the louse excreta.

Table XIX.

\begin{tabular}{|c|c|c|c|c|c|}
\hline $\begin{array}{l}\text { Exp. } \\
\text { no. }\end{array}$ & $\begin{array}{l}\text { Interval in days between } \\
\text { infection of lice and } \\
\text { collection of excreta }\end{array}$ & $\begin{array}{l}\text { No. of } \\
\text { lice used }\end{array}$ & \multicolumn{2}{|c|}{ Route } & Result \\
\hline 23 & 1 & 500 & \multicolumn{2}{|c|}{ Scarified skin } & - \\
\hline 39 & 1 & $\ldots$ & , & , & - \\
\hline 24 & 3 & 400 & , & ", & - \\
\hline 25 & 5 & 400 & , & ״ & - \\
\hline 53 & 5 & $\ldots$ & $"$ & " & + \\
\hline 41 & 6 & $\ldots$ & $"$ & ", & - \\
\hline 54 & 6 & $\ldots$ & , & $"$ & - \\
\hline 42 & 7 & $\ldots$ & ״ & $"$ & + \\
\hline 55 & 7 & $\ldots$ & $"$ & " & + \\
\hline 26 & 8 & 400 & " & " & - \\
\hline 43 & 8 & $\ldots$ & , & , & - \\
\hline 91 & 8 & $\ldots$ & , & ", & - \\
\hline 45 & 9 & $\ldots$ & , & „, & + \\
\hline 46 & 10 & $\ldots$ & $"$ & $"$ & + \\
\hline 59 & 11 & $\ldots$ & ", & ", & + \\
\hline 27 & 12 & $\ldots$ & , & " & + \\
\hline 30 & 23 & $\ldots$ & , & „, & + \\
\hline
\end{tabular}

It is shown by the above table that the excreta were first found to be infective five days after the infected feed. From the ninth day the results were invariably positive. It would appear from this that the organism of Trench Fever undergoes multiplication in the intestine of the louse and that from the fifth day onwards they may be so numerous in the excreta as to be capable of infecting healthy men.

10. To ascertain what percentage of lice fed upon trench fever cases become infected.

Table XX.

\begin{tabular}{ccc} 
Exp. no. & \multicolumn{2}{c}{ Inoculation of } \\
60 & Excreta of 10 lice \\
66 &, &, 5 , \\
71 &, &, 1 louse \\
79 &, &, $1 \quad$ "
\end{tabular}

$\begin{array}{cc}\text { Route } & \text { Result } \\ \text { Scarified skin } & + \\ , " & + \\ ", & + \\ ", & +\end{array}$

Nature of experiment. Ten clean lice were fed twice daily on a Trench Fever case for a period of 18 days. The excreta passed during the last three days of that time, that is the 16,17 and 18th days, were collected and inoculated into a scarified skin area (Exp. 60).

Meanwhile the lice had been separated into two batches of five each, and fed as usual on the same patient. The excreta passed by one batch of five were collected during the next seven days and inoculated into the skin (Exp. 66). 
Two lice only of this same batch of five continued to live and thrive. For some time past the individual lice had been housed separately in glass tubes and kept in an incubator at $32^{\circ} \mathrm{C}$.

The excreta of one of these lice were collected for five days and inoculated into a healthy man (Exp. 71); from the other in the same way into another volunteer (Exp. 79). All these experiments proved to be positive.

It may therefore be concluded that a high percentage of lice become eventually infected; and that the excreta from one louse collected for five days may be sufficient to produce a severe and typical attack of Trench Fever.

\section{Hereditary transmission of the organism in the louse.}

\section{Table XXI.}

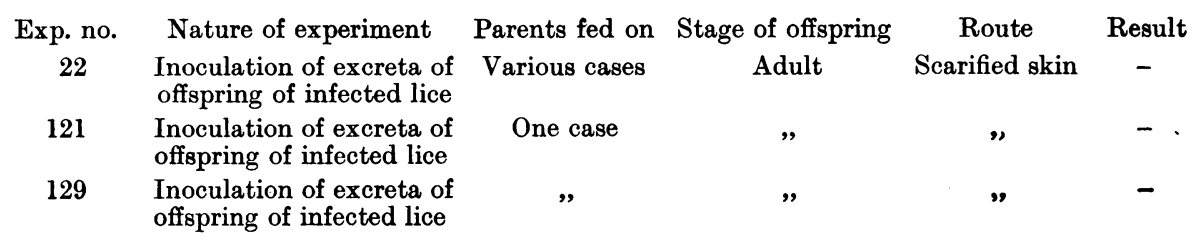

From these three experiments it would appear that the microorganism of Trench Fever is not passed from infected lice to their offspring.

It may be added that the excreta of the parent lice had been proved to be infective. Great care was taken to prevent the carriage of infective material on the outside of the eggs. They were washed thoroughly in lysol and afterwards in sterile water, dried and placed in clean boxes. When hatched out they were fed on a healthy person until they were adults. After the young lice had fed as adults for the necessary period (10 to 15 days or more) and having been kept in the proper temperature their excreta was collected and used in the above experiments.

12. To ascertain if Pediculus capitis can convey the virus of trench fever.

Only one experiment (No. 151) was made. The head-lice were fed in the usual way on a Trench Fever case; their excreta collected and rubbed into a scarified area of the skin of a healthy volunteer. The result was positive. We may therefore conclude that $P$. capitis can also carry the organism of Trench Fever from the sick to the healthy.

13. To ascertain the minimal infecting dose of louse excreta.

Table XXII.

\begin{tabular}{|c|c|c|c|c|c|c|}
\hline $\begin{array}{c}\text { Exp. } \\
\text { no. }\end{array}$ & \multicolumn{2}{|c|}{$\begin{array}{c}\text { Amount of } \\
\text { excreta }\end{array}$} & \multicolumn{2}{|c|}{$\begin{array}{c}\text { Treatment of } \\
\text { excreta }\end{array}$} & Route & Result \\
\hline 102 & 0.05 & gm. & Dissolvec & .c. N.S. & Sub-cutaneous & - \\
\hline 109 & 0.1 & , & " & , & " & - \\
\hline 97 & $0 \cdot 1$ & " & " & , & ” & + \\
\hline 117 & $1 \cdot 0$ & " & $"$ & , & , & + \\
\hline 96 & $2 \cdot 0$ & , & ", & " & ", & + \\
\hline
\end{tabular}


From the above five experiments it would appear that a tenth of a milligram of excreta is sufficient to give rise to the disease.

\section{VIABILITY OF THE TRENCH FEVER ORGANISM.}

1. To ascertain the effect of drying on the organism contained in the blood of trench fever cases.

Table XXIII.

\begin{tabular}{|c|c|c|c|c|c|c|}
\hline $\begin{array}{l}\text { Exp. } \\
\text { no. }\end{array}$ & $\begin{array}{l}\text { Amount } \\
\text { injected }\end{array}$ & $\begin{array}{l}\text { Day of } \\
\text { disease }\end{array}$ & Treatment of blood & $\begin{array}{c}\text { Interval } \\
\text { between } \\
\text { collection and } \\
\text { experiment }\end{array}$ & Route & Result \\
\hline 137 & 5 c.c. & 1 & $\begin{array}{l}\text { Dried over sulphuric acid } \\
\text { for } 39 \text { hours }\end{array}$ & 42 hours & Subcutaneous & - \\
\hline 175 & 10 c.c. & 5 & Dried over sulphuric acid & 46 hours & Intramuscular & - \\
\hline
\end{tabular}

Two experiments, Nos. 137 and 175, were made on the effect of drying Trench Fever blood. The blood was dried over sulphuric acid for about 40 hours; the residue redissolved and injected into two healthy men.

Both experiments were unsatisfactory as the controls also failed to take the disease. The experiments were made on the analogy of South African Horse-sickness, the ultramicroscopical organism of which is said to be destroyed by drying. It seems very unlikely in the case of Trench Fever that the organism will be so easily destroyed in the blood seeing that the dried excreta of infected lice retain their power of infection for a long time. But it is possible that the organism in the blood and in the excreta may differ in their powers of resistance.

Conclusion. The effect of drying on the virus of Trench Fever contained in the blood remains unproven; if an opportunity of repeating the experiment is found it should be taken.

\section{Exposure to sunlight.}

One experiment. (No. 21) was made to test the effect of sunlight on the Trench Fever organism. The dried excreta of infected lice were placed in a glass tube and exposed frequently to sunlight for 16 days. At the end of this time the excreta were rubbed into a scarified area of skin of a healthy man. The result was positive. It may therefore be concluded that exposure to sunlight for several days does not sterilise infected excreta.

No attempt was made to try the effect of sunlight on the virus in the blood.

3. Effect of distilled water on the virus.

Table XXIV.

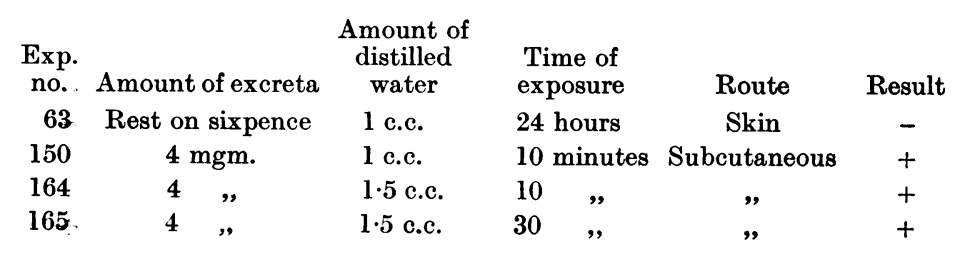


These experiments arose out of Exp. 5 in which 2.7 c.c. of infected blood, 10 c.c. of which had been laked by the addition of 170 c.c. distilled water, failed to give rise to the disease. Exp. 63 was also negative but was not satisfactory on account of the technique used, and also because the man was suspected of being naturally immune. The other three experiments were positive and prove that distilled water has no effect on infective excreta up to an exposure of 30 minutes.

Conclusion. There is some evidence, although unsatisfactory, that distilled water destroys the virulence of the virus in blood, and also in excreta if the exposure is prolonged. Exposure up to 30 minutes is without effect.

\section{How long do louse excreta remain infective?}

Table XXV.

$\begin{array}{rcc}\text { Exp. } & \begin{array}{c}\text { Amount of } \\ \text { excreta }\end{array} & \begin{array}{c}\text { Temp. } \\ \text { kept at }\end{array} \\ 57 & \cdots & \text { Room } \\ 95 & \cdots & ” \\ 178 & 8 \mathrm{mg} . & ” \\ 195 & 40 \% & \#\end{array}$

\begin{tabular}{|c|c|c|c|c|}
\hline \multirow{2}{*}{\multicolumn{2}{|c|}{$\begin{array}{l}\text { Length } \\
\text { of time } \\
60 \text { days }\end{array}$}} & $\begin{array}{l}\text { Nature of } \\
\text { experiment }\end{array}$ & Route & Result \\
\hline & & Rubbed in & Skin & + \\
\hline 120 &, & " & ", & + \\
\hline 275 & , & In 1.5 c.c. N.S. & Subcutaneous & - \\
\hline 365 & , & , & , & - \\
\hline
\end{tabular}

The excreta were stored in glass tubes plugged with cotton-wool and kept at the temperature of the laboratory. Exp. 178 in which the excreta had been kept for nine months, seems satisfactory, but Exp. 195 not so, as the man when tested afterwards for immunity failed to react.

Conclusion. It would appear that the organism in the excreta of infected lice retains its virulence for at least four months when kept in plugged glass tubes at room temperature.

5. At what temperature is the organism in lice excreta killed?

(a) Dry Heat.

\begin{tabular}{|c|c|c|c|c|c|c|c|}
\hline $\begin{array}{c}\text { Exp. } \\
\text { no. }\end{array}$ & $\begin{array}{c}\text { Amount o } \\
\text { excreta }\end{array}$ & Temperature & & & $\begin{array}{c}\text { Nature of } \\
\text { experiment }\end{array}$ & Route & Result \\
\hline 33 & Not stated & $56^{\circ} \mathrm{C}$. & 20 & inutes & Rubbed in & Skin & + \\
\hline 58 & , & $65^{\circ}$, & 20 & ", & , & " & + \\
\hline 73 & ", & $70^{\circ}$, & 20 & ” & , & , & + \\
\hline 84 & „, & $80^{\circ}$, & 20 & " & , & ", & + \\
\hline 94 & ” & $100^{\circ}$, & 20 & ” & , & , & - \\
\hline
\end{tabular}

It would appear from the above experiments that lice excreta retain their virulence after exposure to a dry heat of $80^{\circ} \mathrm{C}$. for 20 minutes; but lose it at a temperature of $100^{\circ} \mathrm{C}$.

(b) Moist Heat.

Table XXVII.

\begin{tabular}{|c|c|c|c|c|c|c|}
\hline $\begin{array}{c}\text { Exp. } \\
\text { no. }\end{array}$ & $\begin{array}{c}\text { Amount of } \\
\text { excreta }\end{array}$ & Temperature & Time & $\begin{array}{c}\text { Nature of } \\
\text { experiment }\end{array}$ & Route & Result \\
\hline 34 & Not stated & $80^{\circ} \mathrm{C}$. & 10 minutes & Rubbed in & Skin & - \\
\hline 82 & " & $70^{\circ}$ & 20 & , & " & - \\
\hline 83 & " & $60^{\circ}$, & 20 & , & " & - \\
\hline
\end{tabular}


From these three experiments it would appear that the organism of Trench Fever is destroyed when exposed to a moist heat of $60^{\circ} \mathrm{C}$. for 20 minutes.

The method of carrying out these experiments on the action of dry and moist heat is detailed by Byam and his colleagues in their book entitled Trench Fever, in the chapter on prophylaxis. They state that the American Red Cross Commission on Trench Fever found that the virulence of the excreta was not destroyed by exposure to $60^{\circ} \mathrm{C}$., moist heat, for 30 minutes, but that it was destroyed by exposure to $70^{\circ} \mathrm{C}$., moist heat, for a similar time. They are unable to account for this discrepancy.

It is unnecessary to go further into the question of the destruction of lice, their eggs and the virus of the excreta in this report, since all these points are dealt with in the above-mentioned book and in various papers the titles of which are given in the bibliography.

6. Effect of ultra-violet rays on the organism.

Table XXVIII.

\begin{tabular}{|c|c|c|c|c|c|}
\hline $\begin{array}{l}\text { Exp. } \\
\text { no. }\end{array}$ & Amount of excreta & Dose of rays & Time & Route & Result \\
\hline 62 & Not stated & Until all the bacteria were killed & Not stated & Skin & + \\
\hline 155 & "' & 4 times lethal dose for anthrax spores & " & & + \\
\hline 134 & $4 \mathrm{mgm}$. & 3 times lethal dose for bacteria & , & Subcut. & + \\
\hline 168 & $\begin{array}{l}4 \text { mgm. in } \\
1.6 \text { c.c. N.S. }\end{array}$ & $\begin{array}{c}\text { Fully lethal } 4 \text { times for most } \\
\text { organisms }\end{array}$ & 30 minutes & , & + \\
\hline
\end{tabular}

These experiments were carried out by Mr Barnard, one of the members of the Committee. The lice excreta were exposed in Exp. 155 to four times the lethal dose for anthrax spores. They gave bacterial growth before but none after exposure, in either aerobic or anaerobic cultures. For details the different experiments should be consulted. Barnard states in regard to Exp. 134 that the excreta received three times the lethal dose of ultra-violet light for ordinary bacteria. If however the organisms were smaller than the mean wave-length he was using they would escape destruction.

7. Effect of antiseptic and other chemical substances.

Table XXIX.

\begin{tabular}{|c|c|c|c|c|c|c|}
\hline $\begin{array}{l}\text { Exp. } \\
\text { no. }\end{array}$ & $\begin{array}{c}\text { Amount of } \\
\text { excreta }\end{array}$ & Chemical & Time & Temperature & Route & Result \\
\hline 74 & Not stated & $2 \%$ lysol & 20 minutes & $20^{\circ} \mathrm{C}$. & Skin & - \\
\hline 75 & ", & $2 \%$ Army soap and & $20 "$ & $47 \cdot 6^{\circ}$ to $38^{\circ} \mathrm{C}$. & , & + \\
\hline 80 & , & $2 \%$ cresol & 22, & $18 \cdot 5^{\circ} \mathrm{C}$. & , & - \\
\hline 209 & $0.2 \mathrm{gm}$. & $\begin{array}{l}3 \text { c.c. glycerine and } \\
3 \text { c.c. N.S. }\end{array}$ & 10 days & $\cdots$ & " & - \\
\hline 211 & 3 mgm. & $\begin{array}{l}\text { Equal parts of glycerine } \\
\text { and N.S. }\end{array}$ & 7 days & $\ldots$ & Subcut. & + \\
\hline
\end{tabular}

These experiments go to show that 2 per cent. of lysol or cresol solution is sufficient to render lice excreta harmless, but an exposure of seven days to equal parts of glycerine and salt solution has no effect. 


\section{ARE ANY OF THE LABORATORY ANIMALS SUSCEPTIBLE TO TRENCH FEVER?}

This question must be answered for the present in the negative, or at least as not proven. Arkwright inoculated several monkeys with infective excreta, but none of the animals showed any marked reaction. Lice were fed on one of them, and their excreta afterwards used to inoculate Exp. 61 who however did not react in the slightest degree.

Ledingham on his return from Active Service in May 1919 took up the question of the transmissibility of the Trench Fever virus to laboratory animals. He summarises the results as follows:

(1) Experiments (about 50 in all) undertaken with the object of transmitting Trench Fever to laboratory animals proved in the main negative. A very small minority of inoculated rabbits and guinea-pigs, however, exhibited temperature charts which at least suggested a successful transmission of the virus. The question must for the present remain undecided, but it is probable that a certain small percentage of normal rabbits and guinea-pigs may be susceptible to the virus.

(2) In the course of the work it was established that the Rickettsia present in the excreta of lice fed on Trench Fever patients are agglutinated in the presence of immune serum obtained from animals immunised with infective lice excreta.

(3) Trench Fever Rickettsia are not agglutinated by the serum of animals immunised with the excreta of normal uninfected lice.

Ledingham failed to obtain samples of blood from recent cases of Trench Fever in order to ascertain whether the reaction possesses a diagnostic value. None of the old chronic cases which were available gave any reaction.

\section{IMMUNITY.}

\section{To ascertain what percentage, if any, of men are naturally immune to} trench fever.

The subjects of the eleven experiments given in Table XXX were men who had been subjected to various experiments to which they had not reacted. For example No. 145 had passed through four such experiments, the last of which consisted of the inoculation of $2 \mathrm{mgm}$. of infective excreta. To ascertain if he were really immune $8 \mathrm{mgm}$. were given, but to this large dose he also failed to react. It is possible that the previous four experiments had in some way brought about this immunity, but if not, then this man must be regarded as a case of natural immunity. In the same way Nos. 160 and 197 may be looked on as cases of natural immunity. Out of all the men used for these experiments, some 216 in number, only three were detected as being probably naturally immune.

It may then be concluded that only a very small proportion of the population are naturally immune to the disease. 


\begin{tabular}{|c|c|c|c|c|c|}
\hline \multirow[b]{2}{*}{$\begin{array}{l}\text { Exp. } \\
\text { no. }\end{array}$} & \multicolumn{4}{|c|}{ Table XXX. } & \multirow[b]{2}{*}{ Result } \\
\hline & $\begin{array}{l}\begin{array}{c}\text { Previous negative } \\
\text { experiments }\end{array} \\
\text { No. }\end{array}$ & $\underset{\text { excreta }}{\text { Amount of }}$ & $\begin{array}{l}\text { Treatment of } \\
\text { inoculum }\end{array}$ & Route & \\
\hline 145 & 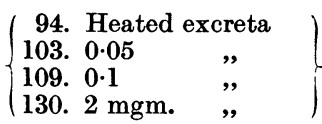 & $8 \mathrm{mgm}$. & 0.5 c.c. N.S. & Subcutaneous & - \\
\hline 160 & $\left\{\begin{array}{l}\text { 140. Distilled water } \\
\text { 154. Lice kept at } 30^{\circ} \text { C. }\end{array}\right.$ & $"$ & $"$ & $"$ & - \\
\hline 162 & $\left\{\begin{array}{l}\text { 131. Lice excreta } \\
\text { 144. Lice fed once } \\
\text { 156. One louse }\end{array}\right\}$ & " & " & " & + \\
\hline 163 & 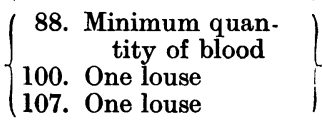 & $"$ & $"$ & $"$ & + \\
\hline 179 & $\left\{\begin{array}{l}\text { 153. Filtration } \\
\text { 159. Urine }\end{array}\right.$ & $"$ & $"$ & $"$ & + \\
\hline 186 & $\left\{\begin{array}{l}\text { 149. Feeding lice } \\
\text { 178. Lice } 275 \text { days old }\end{array}\right\}$ & Not stated & None & Skin & + \\
\hline 189 & $\begin{array}{l}\text { 174. Whole blood } \\
\text { 188. lst day of disease }\end{array}$ & $"$ & $1 \cdot 5$ c.c. N.S. & Subcutaneous & + \\
\hline 196 & $\left\{\begin{array}{l}\text { 191. Ex } \\
\text { 194. Excreta of lice }\end{array}\right.$ & ", & None & Skin & + \\
\hline 197 & $\left\{\begin{array}{ll}173 . & 0 \cdot 2 \text { c.c. blood } \\
195 . & \text { Excreta } 1 \text { year old }\end{array}\right\}$ & " & None & ", & - \\
\hline 201 & $\left\{\begin{array}{ccc}\text { 201. } & \text { Small dose excreta } \\
201 . & \# \\
201 . & \#\end{array}\right\}$ & $5 \mathrm{mgm}$. & N.S. & Subcutaneous & + \\
\hline 210 & 206. Supposed case & Not stated & $0 \cdot 7$ c.c. N.S. & " & + \\
\hline
\end{tabular}

2. To ascertain if one attack of trench fever confers immunity.

This is an important question and one which it is difficult to answer categorically. It must be remembered that the disease is often an extremely chronic one. Lice fed on two patients 298 and 443 days after the onset of the fever (Exps. 72 and 181) became infected, showing that the virus still persisted in the patient's blood. The fact of the Trench Fever parasite being able to live so long in the blood is an argument that the tissues of the body have little power of dealing with it. It would be well in testing for immunity to make sure that the patient was completely recovered from his first attack. If a case has still the living virus in his blood it is not to be wondered at if he shows no reaction to the testing dose. In the same way it is not to be wondered at if the case does show a reaction, the slight addition of poison being enough to upset the equilibrium.

Byam and his fellow workers made many experiments to test this question, but in few of them was it first proved that the case was free from infection or had completely recovered. Many of them were obviously still suffering from the disease. The experiments are divided into different categories.

In the first place let us consider the effect of the disease contracted naturally in France. The men were admitted to the Hampstead Hospital suffering from Trench Fever or its sequelæ. After they had apparently recovered, the tempera- 
ture being normal and the signs of acute disease having disappeared; they were tested as to their immunity to further attack by being inoculated with Trench Fever blood or infected lice excreta.

The following table gives the result of the attempt to reinfect with Trench Fever blood injected intravenously. The average number of days since the onset of disease is 85 days.

(a) To ascertain if men who have suffered from trench fever acquired naturally, are immune to a second attack when trench fever blood is injected intravenously.

\begin{tabular}{|c|c|c|}
\hline $\begin{array}{l}\text { Exp. } \\
\text { no. }\end{array}$ & \multicolumn{2}{|c|}{$\begin{array}{c}\text { Time after onse } \\
\text { of disease }\end{array}$} \\
\hline 35 & 62 & days \\
\hline 37 & 99 & , \\
\hline 49 & 98 & , \\
\hline 65 & 119 & , \\
\hline 108 & 80 & , \\
\hline 110 & 85 & , \\
\hline 111 & 70 & , \\
\hline 112 & 65 & , \\
\hline
\end{tabular}

Amount
of blood
5 c.c.
$5, "$
5,
$4, "$
20,
20,
20,
20,

Table XXXI.

Table XXXI shows that of eight cases, six gave a negative reaction, and two a positive. With the exception of one, all were still suffering from the effects of the fever. The number of positive reactions is small, which may be accounted for by the fact that Trench Fever blood at no time seems to contain much of the virus.

It is evident that these cases do not answer the question as to whether one attack confers immunity or not.

(b) To ascertain if men who have suffered from naturally acquired trench fever are immune to a second attack when infected lice excreta are inoculated.

Let us see what is the effect of the inoculation of infected lice excreta on these apparently recovered cases. As lice excreta are more virulent than Trench Fever blood, more positive results would be anticipated.

Table XXXII gives a list of the men who acquired the disease naturally and were afterwards tested by lice excreta, either rubbed into a scarified area of the skin or made into an emulsion and injected subcutaneously. The average number of days since the onset of the disease is 114 days.

\begin{tabular}{|c|c|c|c|c|}
\hline \multirow{3}{*}{$\begin{array}{l}\text { Exp. no. } \\
\qquad 20\end{array}$} & \multirow{2}{*}{\multicolumn{2}{|c|}{ Time after onset }} & \\
\hline & & & $\begin{array}{l}\text { Amount } \\
\text { of excreta }\end{array}$ & Condition when tested \\
\hline & 120 & lays & Not given & Bradycardia \\
\hline 51 & 115 & ", & , & D.A.H. debility \\
\hline 52 & 117 & , & , & Dyspepsia and pains \\
\hline 76 & 134 & " & ", & Giddiness and pains \\
\hline 85 & 48 & , & , & Headache and pains \\
\hline 86 & 52 & , & , & Pain in back and legs \\
\hline 90 & 149 & , & , & Slight fever and dizziness \\
\hline 104 & 194 & , & 8 mgm. & Fit \\
\hline
\end{tabular}

$\begin{array}{cc}\text { Route } & \text { Result } \\ \text { Skin } & + \\ " & + \\ " & + \\ " & - \\ " & - \\ " & + \\ \text { Subcutaneous } & +\end{array}$


Here again there are eight cases, but now five are positive and only three negative. In one of the negative cases the infectivity of the louse excreta was doubtful and in the other two, the lice were fed on the patients themselves. If these three unsatisfactory cases are left out, then all the remainder are positive, with an average incubation period of 10 days.

It may therefore be asserted that cases of Trench Fever with an average of 114 days from the onset of the disease will as a rule show a definite reaction if inoculated with infected lice excreta. Whether this is really a fresh attack of the disease or merely a relapse or superinfection is doubtful. It may be noted that only one of the men is reported as being fit, all the others were still suffering from the effects of the fever. It will also be remembered that in some cases lice fed on old cases up to 443 days after the onset of the disease became infected, showing that the organism was still present in the blood. These experiments would go to show that the production of immunity in man is slow and imperfect.

(c) To ascertain if men who have passed through one attack of trench fever, artificially acquired, are immune to a second attack, when trench fever blood is injected or lice excreta inoculated.

It now remains to enquire into the cases which were given the disease artificially by the inoculation of Trench Fever blood or infected lice excreta. These were the volunteers who had been successfully infected with the fever in the course of various experiments. Table XXXIII gives the experimental numbers of these cases, their condition as to health when tested, the length of time which had elapsed since the onset of the fever, the method of testing, whether by blood or lice excreta, and the result.

Table XXXIII.

\begin{tabular}{|c|c|c|}
\hline Exp. no. & \multirow{2}{*}{\multicolumn{2}{|c|}{$\begin{array}{c}\text { Time after onset } \\
\text { of disease } \\
30 \text { days }\end{array}$}} \\
\hline 28 & & \\
\hline 29 & 31 & „, \\
\hline 70 & 139 & ״ \\
\hline 89 & 119 & ” \\
\hline 98 & 154 & ” \\
\hline 99 & 132 & „, \\
\hline 103 & 48 & ", \\
\hline 105 & 182 & , \\
\hline 114 & 76 & ", \\
\hline 115 & 122 & , \\
\hline 116 & 116 & ", \\
\hline 125 & 139 & ”, \\
\hline
\end{tabular}

$\begin{array}{cc}\begin{array}{c}\text { Condition when } \\ \text { tested }\end{array} & \begin{array}{c}\text { Amount of blood } \\ \text { or excreta } \\ \text { Pains }\end{array} \\ \text { Uncertain } \\ \text { Falpable spleen } & , \\ " & \text { " } \\ " & \text { Uncertain } \\ " & \text { " } \\ " & 20 \text { c.c. } \\ " & 20 \text { mgm. } \\ " & 4 \text { mgm. } \\ " & 50 \text { c.c. } \\ , & ,\end{array}$

\begin{tabular}{|c|c|}
\hline Route & Result \\
\hline Skin & - \\
\hline " & - \\
\hline Vein & + \\
\hline Vein & - \\
\hline Skin & - \\
\hline Vein & $\begin{array}{l}+ \\
-\end{array}$ \\
\hline Subcutaneous & - \\
\hline & - \\
\hline Vein & - \\
\hline " & - \\
\hline "' & - \\
\hline
\end{tabular}

There are twelve of these cases with an average of 108 days since the onset of the disease. Of these two were still unfit, the remainder fit. Only two out of the twelve gave a positive reaction, the other eight proved refractory to the testing dose. One, No. 105, was tested with large doses on three separate occasions, the last time six months after the onset of the fever. 
Conclusion. With the data at our disposal it is not possible to give a categorical answer to the question, does one attack of Trench Fever confer immunity? Taking everything into consideration, it is probable that one attack does not confer immunity as, for example, is understood in measles, scarlet fever or small-pox; but rather a partial and limited immunity as in influenza or pneumonia.

\section{ETIOLOGY.}

1. Rickettsia-like organisms found in the excreta of infected lice.

Three members of the War Office Trench Fever Committee, the late Professor Plimmer, F.R.S., and Dr Arkwright and Mr Bacot of the Lister Institute, devoted themselves to the search for a causal organism in Trench Fever. Professor Plimmer exhibited preparations made from the excreta of infected lice which showed enormous numbers of very small bodies. These bodies resembled the Rickettsia described by Töpfer and Rocha-Lima in 1916 as occurring in lice of Trench Fever patients, and led Arkwright and Bacot to follow up this line of research. It is not necessary here to consider their results in detail as they have been fully described in a paper entitled "The Association of Rickettsia with Trench Fever," by J. A. Arkwright, A. Bacot and Martin Duncan (Journ. Hygiene, xvIII. 76-94, Pls. II, III). It will be sufficient here to quote their conclusions:

\section{Conclusions.}

1. The intimate association in lice of Rickettsia with the virus of Trench Fever appears to have been amply proved.

2. The examinations of lice which have fed on healthy civilians in England have given negative results in a sufficiently uniform manner to constitute a significant negative control, but further examinations of lice from normal civilians are desirable.

3. Lice from soldiers who have been in France, or who have mixed with men from France in this country, would not afford a satisfactory control, since the infection of Trench Fever with the power of infecting lice with Trench Fever virus and Rickettsia may be very long lasting.

4. Whether Rickettsia constitutes the virus of Trench Fever or are in some way produced by it remains undecided because Rickettsia cannot be cultivated on artificial media.

5. It is conceivable that Rickettsia are not living microorganisms, but their appearance certainly suggests that they are bacteria, and their remarkable association with Trench Fever virus in the louse further suggests that they are the causal agent of Trench Fever.

2. To ascertain if lice which show Rickettsia in their excreta are infective.

The following experiments on the relation of the presence of Rickettsia in louse excreta to the infectivity of the excreta were made by Major Byam and his co-workers at Hampstead Hospital on behalf of Arkwright and his colleagues and are simply recorded here as they are fully discussed by these workers in their paper quoted above. 


Exp.
no.
100
101
142
143
156
157
166
167
106
107
122
123
144
148

Nature of
experiment
Gut contents 1 louse
" louse
$"$
$"$
$"$
$"$
$"$
$"$
$"$
Excreta
$"$

Table XXXIV.

3. To ascertain how early in the disease a patient can cause lice fed on him to show Rickettsia.

A number of boxes containing healthy lice were prepared. Each box was fed for one day on a case of Trench Fever. The box was then fed on a healthy man and the excreta examined for Rickettsia from day to day. Table XXXV gives the result.

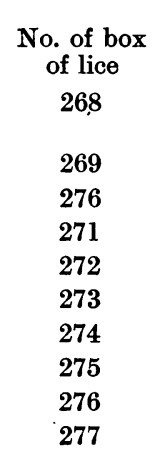

Table X
Fed on case of
Trench Fever
1 day before on-
set, 3 feeds
1st day
1st ",
2nd ",
3rd "
4th ",
5th ",
6th ",
7th ",
8th ",

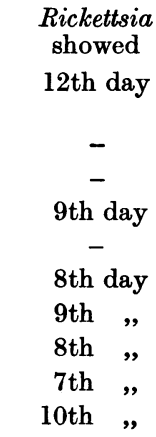

Result
+
-
-
+
-
+
+
+
+
+

It is evident from these experiments that lice fed on Trench Fever cases in the first days of the illness, in one case on the day preceding the onset of the fever, developed Rickettsia in the excreta. The experiments also show on what day after the infecting feed these bodies appear. The earliest is the seventh day, the latest the twelfth, the average the ninth.

\section{TO ASCERTAIN IF THE TRENCH FEVER ORGANISM CAN BE TRANSMITTED BY OTHER BLOOD-SUCKING INSECTS.}

\section{By the bug.}

An experiment (No. 113) was made in order to find out if Trench Fever can be transmitted by the bites of bugs. The box of bugs was fed on a Trench 
Fever case for nearly a month, their excreta collected and injected into a healthy man. The result was negative.

Another experiment (No. 158) was made to ascertain if Rickettsia appeared in the excreta of the bug after feeding on a Trench Fever case. The bugs were only fed once on the first day of the disease. It was thought that Rickettsia did show in the excreta, but these proved negative when inoculated into Exp. 161. Exp. 158 is unsatisfactory as lice fed at the same time and on the same patient did not develop Rickettsia nor were they infective. In connection with this it may be pointed out that a hereditary Rickettsia-like parasite of the bed bug has been described by Arkwright, Atkin and Bacot in Parasitology, vol. xIII. No. 1, 14th March, 1921.

From this one experiment it may be concluded that probably the bug does not serve as a carrier, but more experiments are required to settle the question.

\section{TO ASCERTAIN IF THE ORGANISM OF TRENCH FEVER CAN BE CULTIVATED IN ARTIFICIAL MEDIA.}

Three experiments (192, 193 and 206) were made by injecting supposed sub-cultures of the Trench Fever organism grown on Noguchi's medium into three volunteers. These were all negative.

Up to the present then there is no proof that the organism of Trench Fever can be grown on any artificial culture medium.

\section{FILTERABILITY OF THE TRENCH FEVER ORGANISM.}

\section{When present in the blood.}

\section{Table XXXVI.}

$\begin{array}{rrrr}\begin{array}{r}\text { Exp. } \\ \text { no. } \\ 6\end{array} & \begin{array}{r}\text { Amount } \\ \text { injected } \\ 2 \cdot 3 \text { c.c. }\end{array} & \begin{array}{c}\text { Day of } \\ \text { disease } \\ 9 \text { th }\end{array} & \begin{array}{c}\text { Treatment of blood } \\ \text { 10 c.c. blood laked in } 170 \text { c.c. } \\ \text { Aq. dist. added to saline }\end{array} \\ 206 & 12 \text { c.c. } & 6 \text { th } & \begin{array}{c}\text { 10 c.c. blood added to } 4 \text { c.c. } \\ \text { Sod. Cit. Sol. centrifuged } \\ \text { for } 1 \text { hr. } 54 \text { mins. decanted } \\ \text { Barnard's filter }\end{array} \\ 216 & 5 \text { c.c. } & 4 \text { th } & \begin{array}{c}60 \text { c.c. blood citrated, settled } \\ \text { by gravity, 10 c.c. plasma, } \\ \text { Barnard's filter }\end{array}\end{array}$

\begin{tabular}{|c|c|c|}
\hline $\begin{array}{l}\text { Interval between } \\
\text { collection and } \\
\text { experiment }\end{array}$ & Route & Result \\
\hline 1 hour 30 mins. & Vein & - \\
\hline 3 hours 43 mins. & ," & + \\
\hline $9 \frac{1}{2}$ hours & ", & - \\
\hline
\end{tabular}

There were only three filtration experiments made by the War Office Committee with the blood of Trench Fever cases. The first, Exp. 6, was made with laked blood, but as the same laked blood without filtration also gave a negative result, Exp. 6 may be considered a wash-out. The blood which was used in this experiment had been proved to be infective, and its loss of infectivity was supposed to be due to the distilled water used in the process of laking.

The other two experiments were made by Mr Barnard to test collodion 
filters. One was positive and one negative. It is to be hoped Mr Barnard will pursue this line of investigation and publish the results. In the mean time nothing can be concluded from these two experiments.

McNee, Brunt and Renshaw made several experiments with blood in order to establish whether or not the Trench Fever virus is a filter-passer. They do not commit themselves to any definite opinion, but as their hypothesis was that the Trench Fever microorganism is an intra-corpuscular one they were driven to the position that neither the plasma nor the serum could be infective unless broken down corpuscles were contained in it.

The American Red Cross Commission also attempted to filter the virus in the blood, but with negative results. They considered that this was due to the clogging of the pores of the filter by the blood, as from other experiments they had come to the conclusion that the virus is ultra-microscopical and a filter-passer.

\section{When present in the excreta of infected lice.}

The American Red Cross Commission, having failed to filter the virus in blood plasma or serum, turned their attention to the virus in the urine of patients and in the excreta of lice. Five experiments were made; three of these were positive, two negative.

Two experiments with urinary sediment filtered through an unglazed Chamberland filter gave one positive and one negative result. Three experiments with filtered louse excreta gave two positive and one negative result. The filters were tested before and after the operation with Bacillus typhosus.

From these experiments they conclude that at least one stage of the development of the virus of Trench Fever is filterable and ultra-microscopical.

The War Office Committee made eight experiments with filtered emulsions of lice excreta, a summary of which is given in Table XXXVII. Two of these were positive and six negative. Four were made through Chamberland F filters, four through Berkefeld filters.

\begin{tabular}{|c|c|c|c|c|c|c|c|}
\hline \multicolumn{8}{|c|}{ Table XXXVII. } \\
\hline 153 & 20 & & $1 \%$ suspens & $\begin{array}{l}\text { on of louse } \\
\text { ta }\end{array}$ & Vein & - & $\begin{array}{c}\text { Chamberland F., pressure } 350 \\
\text { to } 400 \mathrm{~mm} \text {. Hg. }\end{array}$ \\
\hline 169 & 50 & " & 1 in 40 & N.S. & , & - & $\begin{array}{l}\text { Chamberland filter, pressure } \\
100 \mathrm{~mm} . \mathrm{Hg} \text {. }\end{array}$ \\
\hline 170 & 50 & , & " & , & ", & - & $\begin{array}{l}\text { Chamberland filter, pressure } \\
100 \mathrm{~mm} . \mathrm{Hg} \text {. }\end{array}$ \\
\hline 171 & 50 & $"$ & , & ", & Subcutaneous & - & $\begin{array}{l}\text { Chamberland filter, pressure } \\
100 \mathrm{~mm} . \mathrm{Hg} \text {. }\end{array}$ \\
\hline 187 & 10 & & $\begin{array}{l}0 \cdot 1 \mathrm{gm} . \\
\text { in } N\end{array}$ & $\begin{array}{l}\text { ulsified } \\
\text { S. }\end{array}$ & ", & + & $\begin{array}{l}\text { Berkefeld filter, pressure } 200 \\
\text { to } 300 \mathrm{~mm} .\end{array}$ \\
\hline 190 & 10 & , & $\begin{array}{l}1 \% \text { susp } \\
\text { louse e }\end{array}$ & $\begin{array}{l}\text { Ision of } \\
\text { creta }\end{array}$ & Vein & - & $\begin{array}{l}\text { Berkefeld filter, pressure } 300 \\
\text { to } 350 \mathrm{~mm} \text {. }\end{array}$ \\
\hline 199 & 35 & ", & $0.5 \mathrm{gm} . \mathrm{e}$ & $\begin{array}{l}\text { reta in } \\
\text { N.S. }\end{array}$ & Subcutaneous & + & $\begin{array}{c}\text { Berkefeld filter D., pressure } 600 \\
\text { to } 740 \mathrm{~mm} \text {. }\end{array}$ \\
\hline 200 & 49 & , & 0.5 gm. e & $\begin{array}{l}\text { reta in } \\
\text { N.S. }\end{array}$ & , & - & $\begin{array}{c}\text { Berkefeld filter, E., pressure } 600 \\
\text { to } 740 \mathrm{~mm} \text {. }\end{array}$ \\
\hline
\end{tabular}


Conclusion. The virus of Trench Fever cannot be said to be ultra-microscopical and a filter-passer in the sense these terms are used at the present day. It may rather be concluded that the organism is small since it succeeds in passing through a Berkefeld filter on two occasions. Such a body about the size of the so-called Rickettsia would seem to fulfil the conditions, and the result of the filtration experiments would appear to be rather more in favour of the hypothesis that Rickettsia are the cause of the disease than against it.

\section{SUMMARY.}

1. The organism of Trench Fever is present in the "whole blood."

2. The evidence seems to be in favour of the organism being an extracorpuscular rather than an intra-corpuscular parasite.

3. The smallest quantity of whole blood which has given rise to the disease was 0.5 c.c.

4. The blood is infective from the first day of the disease, and in one case was found to be still infective after 443 days.

5. The microscopical examination of the blood has not up to the present revealed the organism or at least has not differentiated it from other granules present in blood.

6. There is some evidence that the organism may leave the body in the sputum and urine, but the chief and only way which has any practical significance is by means of a blood-sucking insect, the louse.

7. There is no evidence that infection takes place through food, drink or air, but only by inoculation of the organism by means of this insect.

8. The chief method of infection is not, as might be expected, by the bite of the louse, but by the infected excreta of the louse being brought in contact with an abraded surface of the skin.

9. After a louse has fed on a case of Trench Fever, five to nine days elapse before the excreta become infective.

10. If lice are fed on a case for some time a high percentage of the lice become infective.

11. There is no transmission of the organism of Trench Fever from infected lice through the egg to their offspring.

12. The tenth of a milligram of excreta has been found sufficient to set up the disease.

13. The organism of Trench Fever retains its virulence in louse excreta for at least four months.

14. The virulence of lice excreta is lost by exposure to dry heat of $100^{\circ} \mathrm{C}$. for 20 minutes; to moist heat of $60^{\circ} \mathrm{C}$. for a similar time.

15. It is doubtful if any of the laboratory animals are susceptible to Trench Fever. 
16. It would appear that most men are susceptible to the disease, only a very few individuals having been found apparently naturally immune.

17. One attack seems to produce only a partial and limited immunity.

18. In regard to the etiology of Trench Fever there is strong evidence that the Rickettsia-like bodies found in infected louse excreta are the microorganisms of the disease, but as they have never been cultivated outside the body the final proof is still wanting.

19. The organism cannot be said to be a filter-passer; the evidence would seem to be more in favour of its being a small body such as the so-called Rickettsia. 